University of South Carolina

Scholar Commons

6-2001

\title{
Archaeobotanical evidence for pearl millet (Pennisetum glaucum) in sub-Saharan West Africa
}

A. C. D'Andrea

M. Klee

Joanna Casey

University of South Carolina - Columbia, jlc@sc.edu

Follow this and additional works at: https://scholarcommons.sc.edu/anth_facpub

Part of the Anthropology Commons

Publication Info

Published in Antiquity, Volume 75, Issue 288, 2001, pages 341-348.

(c) Antiquity 2001, Cambridge University Press.

This Article is brought to you by the Anthropology, Department of at Scholar Commons. It has been accepted for inclusion in Faculty Publications by an authorized administrator of Scholar Commons. For more information, please contact digres@mailbox.sc.edu. 


\title{
Archaeobotanical evidence for pearl millet (Pennisetum glaucum) in sub-Saharan West Africa
}

\author{
A.C. D'ANDREA, M. KLEE \& J. CASEY*
}

The remains of pearl millet (Pennisetum glaucum) dating to $3460 \pm 200$ and $2960 \pm 370 \mathrm{BP}$ have been recovered at the archaeological site of Birimi, northern Ghana, associated with the Kintampo cultural complex. This finding represents the earliest known occurrence of pearl millet in sub-Saharan Africa. Results indicate that Kintampo peoples developed

effective subsistence adaptations to savannas as well as tropical forest habitats.

Key-words: West Africa, Kintampo, archaeobotany, pearl millet

The origin of agriculture in sub-Saharan West Africa has been associated with the Kintampo, a ceramic Late Stone Age (LSA) cultural complex occupying the region of present-day Ghana during the 4th millennium BP. Archaeological evidence indicates that Kintampo peoples possessed a material culture similar to that of other early farmers, including chipped and ground projectile points, ground stone axes, grinding stones and ceramics. Sedentary village occupation is indicated by remains of daub architecture, occasionally with stone foundations; however rock-shelters also were inhabited (Davies 1962; Flight 1968; Dombrowski 1980; Stahl 1985; Casey 1993). Although often described as the earliest settled agriculturalists of West Africa, the nature of Kintampo subsistence has been the object of speculation for several decades (Davies 1960; Flight 1976; Posnansky 1984; Stahl 1993; Anquandah 1993). Archaeologists have proposed that Kintampo peoples cultivated various cereals and yams (Dioscorea rotundata, D. cayenensis), as well as crop mixtures (Davies 1962: 291; Flight 1976: 218-19; Anquandah 1993: 260); however, direct evidence relating to subsistence has been sorely lacking (Andah 1993: 250-53). Most available data are derived from one rock-shelter site, K6, located in central Ghana near the tropical forest and forest-savanna mosaic boundary (FIGURE 1) (Stahl 1985: 138-42). This locality has produced evidence for the exploitation of domestic ovicaprids (cf. Capra) and hunting of species attracted to clearings or settlement areas, such as large rodents (Thryonomys swinderianus). Plant remains include tropical forest margin species such as oil palm (Elaeis guineensis), incense tree (Canarium schweinfurthii), hackberry (Celtis) and probable legumes (cf. Fabaceae). Related palynological studies indicate that oil palm was cultivated or managed in the region by at least $3500 \mathrm{BP}$ (Sowunmi 1981: 136; Talbot et al. 1984: 185). New macrobotanical data bearing on this question have been recovered during recent excavations at the Birimi site in northern Ghana (Casey et al. 1997). Analysis of Birimi archaeobotanical samples reported in this paper have confirmed the association of domesticated pearl millet (Pennisetum glaucum) with the Kintampo complex.

The Birimi site is situated in an area of dry woodland savanna atop the Gambaga Escarpment in northern Ghana (FIGURE 1). A rich assemblage of Kintampo artefacts has been recovered on the surface and throughout the complex series of pits and lenses of daub architectural remains preserved below. The site extends for approximately one kilometre on both sides of a gully, which was formed by an ancient stream. Eroding sections of the gully edges have exposed a portion of a Kintampo village including the remains of at least 34 daub architectural units. Excavated sections include

\footnotetext{
* D'Andrea, Department of Archaeology, Simon Fraser University, Burnaby, British Columbia, Canada, V5A 1S6. Klee, Universität Basel, Botanisches Institut, Schönbeinstrasse 6, CH-4056 Basel, Switzerland. Casey, Department of Anthropology, University of South Carolina, Columbia SC 29208, USA.*
}

Received 10 October 2000, accepted 14 February 2001, revised 13 March 2001.

ANTIQUITY 75 (2001): $341-8$ 


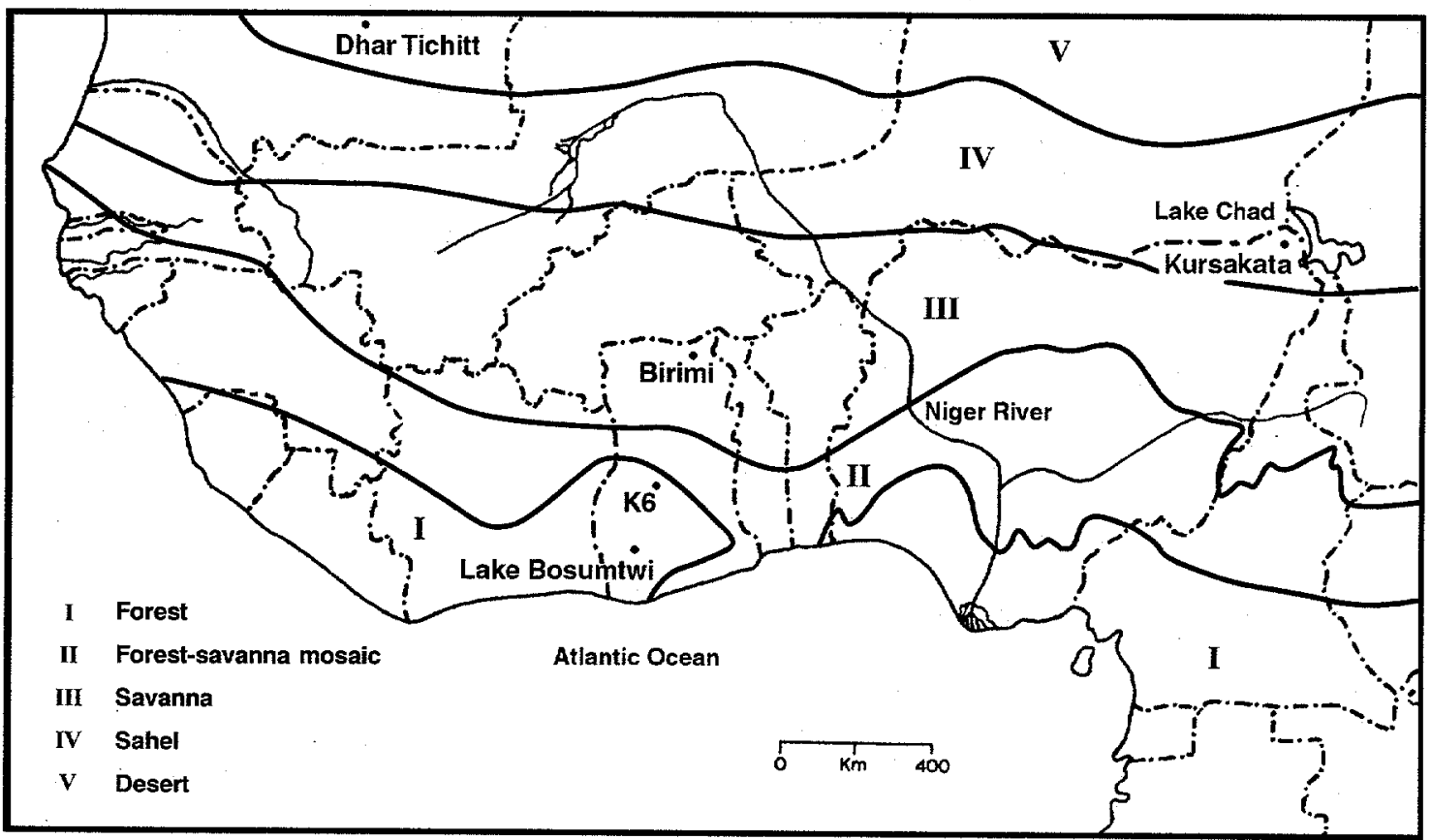

FIGURE 1. Map showing location of sites mentioned in text. Floristic regions after White (1983).

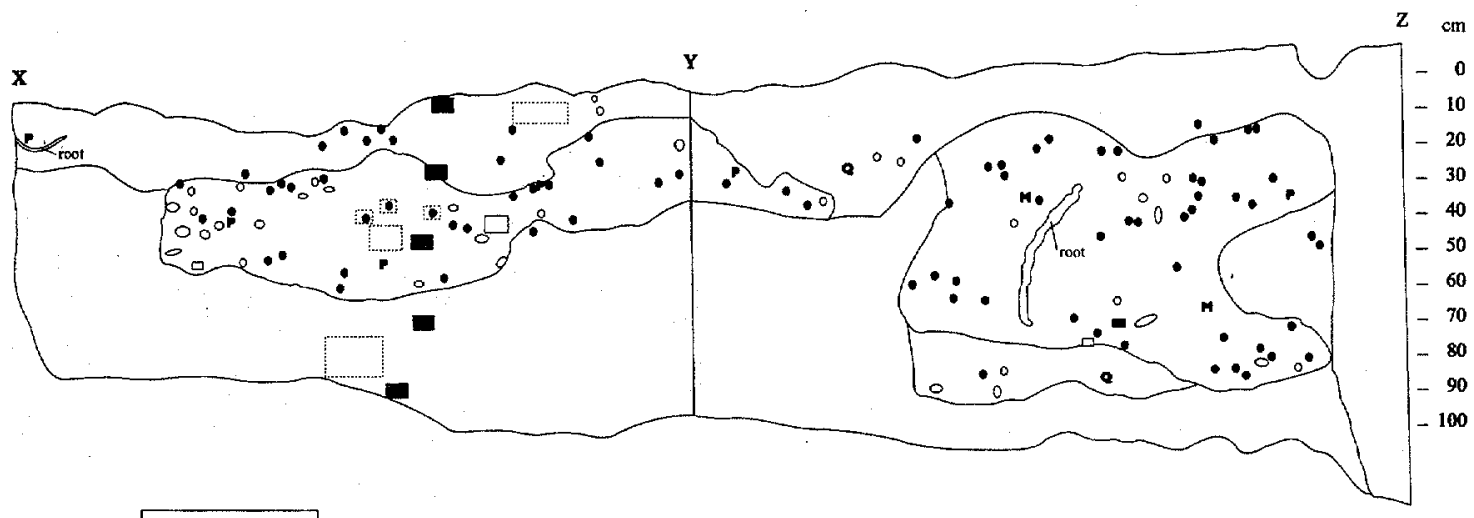

\begin{tabular}{|cl|}
\hline 0 & charcoal \\
$\square$ & daub \\
$\mathbf{W}$ & sandstone \\
$\mathbf{Q}$ & laterite \\
$\mathbf{M}$ & Quartz \\
$\mathbf{P}$ & Mudstone \\
& Pottery \\
& Sediment \\
& Sample \\
\hdashline... & OsL \\
$\vdots$ & Sample \\
\hdashline & Carbon \\
\hdashline & Sample \\
\hline
\end{tabular}

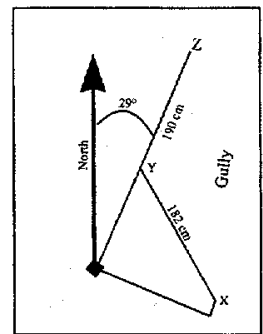

FIGURE 2. Gully profile, pit feature, Birimi.

a profile of the gully, which revealed a welldefined pit feature (FIGURE 2), and area excavations farther upslope. Radiocarbon determinations for the gully profile pit feature based on wood charcoal are summarized in TABLE 1 (Casey et al. 1997).

Birimi was sampled extensively for charred macrobotanical remains. A total of 394 litres 


$\begin{array}{llllll}\begin{array}{l}\text { depth } \\ \text { (cm) }\end{array} & \begin{array}{l}\text { lab } \\ \text { no. }\end{array} & \text { material } & \begin{array}{l}\text { uncalibrated } \\ \text { radiocarbon } \\ \text { year BP* }\end{array} & \begin{array}{l}\text { dendro- } \\ \text { calibrated } \\ \text { age range (BC)* }\end{array} & \begin{array}{l}\text { calibration curve } \\ \text { intercept (cal BC) }\end{array} \\ 32-42 & \text { B-099308 } & \text { charcoal } & 3310 \pm \mathbf{1 1 0} & 1735-1453 & 1596-1528 \\ 42 & \text { B-099306 } & \text { charcoal } & 3240 \pm 90 & 1618-1413 & 1512 \\ 45-50 & \text { TO-8173 } & \text { grain } & 2960 \pm 370 & 1620-795 & 1130-1250 \\ 50-60 & \text { TO-8172 } & \text { grain } & 3460 \pm 200 & 1980-1520 & 1740 \\ 62 & \text { B-099307 } & \text { charcoal } & 3550 \pm 40 & 1942-1777 & 1883\end{array}$

TABLE 1. AMS ${ }^{14} \mathrm{C}$ dates from gully profile pit feature.

* $68 \%$ probability

of sediment taken from the area excavation and gully profile are included in this analysis, all of which were processed using a simple system of manual flotation. Summary results of analyses are presented in TABLE 2 . Samples are dominated by grains of pearl millet (FIGURES 3 \& 4) and probable ( $c f$.) pearl millet, with small quantities of wild grasses, other wild plants and indeterminate seeds. Two pearl millet grain samples from the gully profile pit were submitted for radiocarbon dating by accelerator mass spectrometry (AMS) (TABLE 1). The grains produced low quantities of carbon, resulting in relatively large errors; however, both dates confirm a Kintampo association. These grain ages are consistent with charcoal dates obtained from the same pit (TABLE 1) and with an AMS determination of $3490 \pm 50 \mathrm{BP}(1878-1744 \mathrm{cal}$ BC) obtained from charcoal associated with millet grains in the area excavation (Casey et al. 1997).

Identifications of the Birimi pearl millet specimens ( $P$. glaucum) are based primarily on caryopsis (grain) shape. This feature has been suggested as a more effective criterion than gross grain size for the identification of archaeological pearl millet (Neumann et al. 1996: 443). In addition, caryopsis shape was found to be the most consistent feature in distinguishing variation in a systematic study of floral characters in over 200 accessions of modern pearl millet landraces (Brunken 1977). Although grains of the domesticate are highly variable in size, they are generally obovate (club-shaped), often broadly so, and terete (circular in transverse section). Grains of the wild progenitor ( $P$. violaceum $\left.{ }^{\prime}\right)$ are ellip-

1 P. glaucum is part of a complex of three forms which hybridize freely: the domesticate, wild progenitor, and inlermediale forms or shibras. The nomenclature used follows Claytun \& Renvoize: (1982: 672-3).

Firtkl 3 (right). Pennisetum glaucum caryopsis. area excovation, 53S, 114E, 130-140 cm, Birimi. Dorsal view, $\times 60$. species

count

Pennisetum glaucum

cf. Pennisetum glaucum

domesticates

Dactyloctenium aegyptium

Digitaria

Paniceae

Poaceae

wild grasses

Fabaceae

Mimosaceae

Solanaceae

other wild plants

unknown

unidentifiable

indeterminate

site total

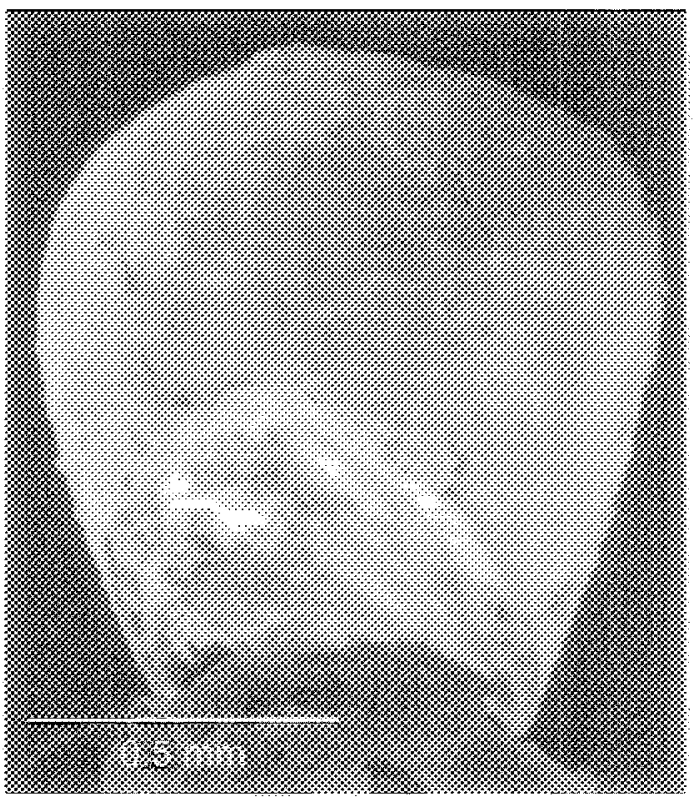

$\%$ total count

1366

300

1666

61.3

2

72

71

146

\section{TABLE 2. Birimi macrobotanical remains.}


a.

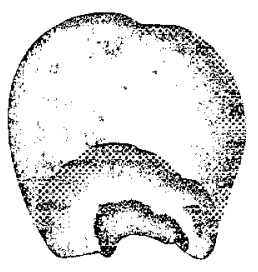

b.

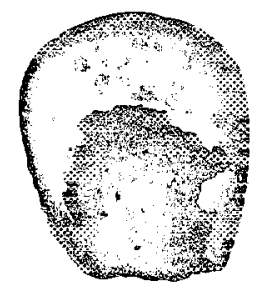

c.

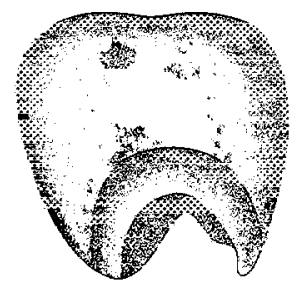

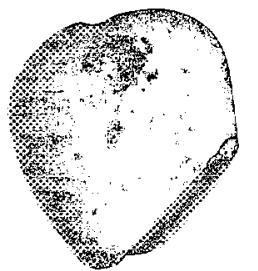
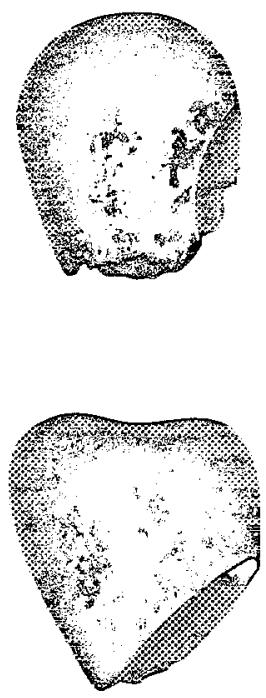
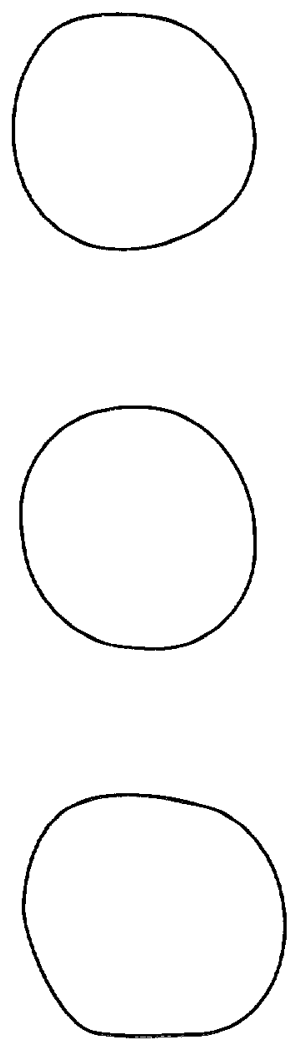

$1 \mathrm{~mm}$
FIGURE 4. Pennisetum glaucum caryopses. dorsal, lateral, and cross-section views: a area excavation 53S 114E, 130-140 cm:

b gully profile, 25$30 \mathrm{~cm}$; c gully profile, 50 $60 \mathrm{~cm}$. tic to lanceolate, and dorsally compressed. Intermediate forms known as shibras ( $P$. sieberanum) produce grains that range from obovate to elliptic, and are terete or moderately compressed; in effect, they are intermediate between domesticated and wild types (Brunken 1977: 165, 169, 170). Shibras are spontaneous mimetic weeds which exist as stable genotypes, the result of introgression between domesticated and wild forms. They developed as a result of weeding practices, and were probably present at the early stages of pearl millet domestication (Brunken et al. 1977: 167-8). Consequently, the occurrence of shibra or shibra-like grains in archaeological deposits implies the existence of domesticated forms. All Birimi specimens identified as P. glaucum, regardless of actual size, conform to the obovate and terete domesticated shape which is clear in both dorsal and lateral views (FIGURE 4). In addition to Pennisetum, modern reference specimens of related genera (including domesticated and wild species), such as Brachiaria, Digitaria, Echinochloa, Panicum, Paspalum, Setaria and Sorghum as well as Cenchrus were examined for comparison, with special emphasis on species used in ancient and recent times by peoples of the Sahara and adjacent regions (Harlan 1989; Wasylikowa 1997; Barakat \& Fahmy 1999). However, none displayed the characteristic club-shape evident in both Birimi specimens and modern landraces of domesticated pearl millet.

The outstanding feature of the Birimi pearl millet is the small caryopsis size compared to modern populations, a trait also noted at the site of Kursakata, Nigeria (FIGURE 1) (Neumann et al. 1996: 443). To illustrate this unusual characteristic, metrical data for 376 undistorted specimens identified to $P$. gloucum were taken for grain thickness vs breadth (T:B). It was not 


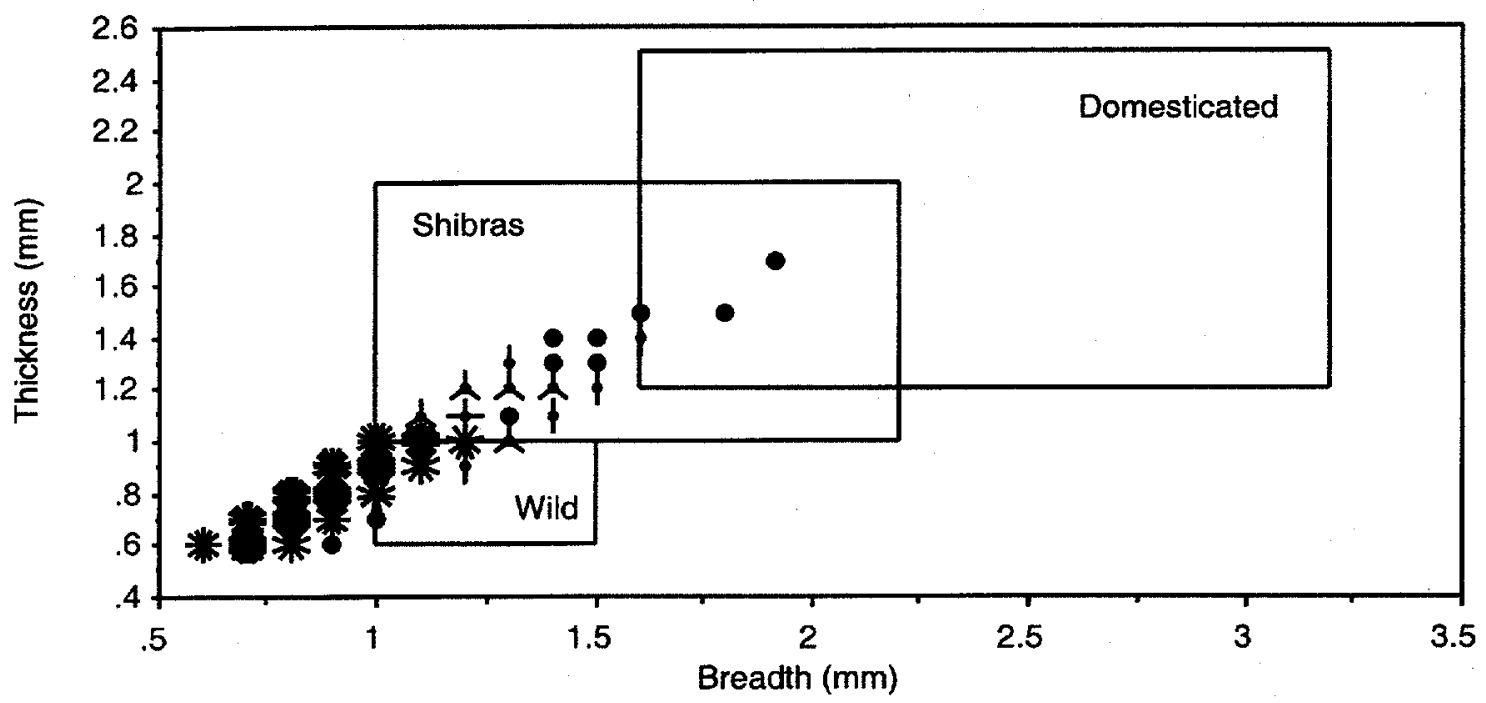

FIGURE 5. Thickness vs. breadth dimensions for measurable charred P. glaucum grains from Birimi. Published ranges for uncharred modern pearl millet, shibras, and wild forms are superimposed (Brunken 1977: 165, 169, 170).

possible to measure length in many specimens, because proximal ends (embryo) were missing. FIGURE 5 and TABLE 3 illustrate Birimi grain $\mathrm{T}: \mathrm{B}$ dimensions in relation to published data for modern pearl millet, the wild progenitor, and shibras, leaving aside the effects of charring in archaeological grains. ${ }^{2}$ As evident in FigURE 5, the majority of measured Birimi domesticated grains, $60 \%$ (226 specimens), have no apparent modern analogue (breadth less than $1.0 \mathrm{~mm}$ ), $23 \%$ (87) fall into the shibra-domesticate range (thickness $\geq 1.0 \mathrm{~mm}$ ), and $17 \%$ (63) actually fall into the size range of modern wild grains (thickness $\leq 1.0 \mathrm{~mm}$ ), although their shape

2 The effects of charring on cereal grain dimensions are not well understood, but experiments indicate that $\mathrm{T}: \mathrm{B}$ ratios tend to remain unchanged because both thickness and breadth increase slightly (Nesbitt 1997: 186). The only available experimental data on charring pearl millet is found in Abdel-Magid (1989: 303) who suggests that grain thickness and breadth increase by $7-8 \%$. Although some parameters of this experiment are unclear, the results are considered acceptable (Nesbitt 1997: 183).

TABLE 3. Birimi and published grain dimensions for pearl millet, wild pearl millet and shibras. is consistent with the domesticated form. The occurrence of several large grain fragments (not measurable) indicates that the percentage of total grains falling into the shibra-domesticate range is somewhat higher. Even so, the use of metrical criteria alone is clearly problematic in the identification of early domesticated forms of pearl millet in the archaeological record. Several factors mitigate against the use of gross grain size in this manner: the astonishing increase in pearl millet inflorescence size as the result of evolution under domestication (Brunken et al. 1977:167); the extreme variability in grain size documented in modern land races (Brunken et al. 1977: 168); and the somewhat unpredictable effects of charring (Nesbitt 1997:186).

The Birimi grain samples fall into the same time range as the earliest known dates on pearl millet at the site of Dhar Tichitt, Mauritania (FIGURE 1). At this locality, organic remains in pottery containing impressions of pearl millet grains and spikelets have produced a determi-

\section{thickness (mm)}

max. min. mean

$\begin{array}{lll}1.7 & 0.6 & 0.8 \\ 2.5 & 1.2 & \text { NA } \\ 2.0 & 1.0 & \text { NA } \\ 1.0 & 0.6 & \text { NA }\end{array}$

\section{grain source}

breadth (mm) max. min. mean

Birimi archaeological modern pearl millet* modern shibras* modern wild *

$\begin{array}{rrr}1.9 & 0.6 & 0.9 \\ 3.2 & 1.6 & \text { NA } \\ 2.2 & 1.0 & \text { NA } \\ 1.5 & 1.0 & \text { NA }\end{array}$


nation of $3500 \pm 100 \mathrm{BP}(1936-1683 \mathrm{cal} \mathrm{BC}$. Ancient pastoralists of Saharan West Africa, such as those occupying Dhar Tichitt, were cultivating pearl millet that was genetically isolated from wild forms by at least 3600 BP (Amblard 1996: 423). The Birimi samples have provided the first indication that this crop was present in sub-Saharan regions in association with Kintampo peoples living about $1000 \mathrm{~km}$ further south. ${ }^{3}$ Evidently, pearl millet was utilized over a relatively widespread region of West Africa during this time, implying an earlier domestication event. The pearl millet preserved at Birimi and Kursakata ${ }^{4}$ (Neumann et al. 1996:433, figure 2; Klee and Zach 1999:86-87), may represent one or more small-grained varieties in existence at the early stages of domestication. If so, it can be postulated that changes in caryopsis shape preceded grain size increases in the domestication of this species. Although thickness measurements of some Birimi grains fall into established ranges for modern domesticated and shibra forms, a significant proportion have breadth dimensions smaller than these extant representatives (FIGURE 5). A possible explanation for this anomaly may lie in the remarkable variation observed in grain characters in modern landraces, caused by introgression with regional populations of the wild subspecies, as well as geographic isolation and human selection over millennia (Brunken et al. 1977:173). This picture of variation is even further complicated if environmental alteration through time is taken into account. Palaeoecological evidence based on water level fluctuations in Lake Bosumtwi, southern Ghana (FIGURE 1), indicates that a period of extreme aridity culminating at $3750 \mathrm{BP}$ is immediately followed by conditions significantly more humid than today which peak at approximately $2420 \mathrm{BP}$ (Talbot et al. 1984: 186, 190). Occupation of Birimi spans the end of this arid phase as well as the ensuing rapid increase in precipitation levels, indicating that

3 Davies (1980: 220) reports the possible occurrence of pearl millet 'cob' impressions in pottery at Ntesero. However, he does not advance this as evidence for cereal agriculture in the absence of a definitive identification, which has not taken place. There also is some uncertainty surrounding the context of the potsherds.

4 It is not possible to provide comparative figures because grain size data are not available. inhabitants were cultivating pearl millet under highly variable environmental conditions. It is difficult to be more specific about the effects of these climatic changes on the inhabitants of Birimi, given the lack of palaeoecological data from northern Ghana.

There is general agreement that pearl millet was domesticated somewhere along the southwestern fringes of the Sahara (Harlan 1971: 47071; Brunken et al. 1977: 173; Tostain \& Marchais 1993: 41-7). A Saharan origin for this domesticate may indicate that it was introduced to Kintampo peoples from the north. This theme of northern origins raises once again the question of sources of influence on the Kintampo complex. Earlier workers believed that the Kintampo developed as the result of population movements out of the Sahara in response to increasing aridity after $4500 \mathrm{BP}$, based on similarities in material remains to cultures occupying the Tilemsi region (Davies 1962: 301; Flight 1976: 216). More recent thinking envisions the Kintampo as a fusion of northern imported and local elements, based on continuity in cultural development evident in the archaeological record (Stahl 1985: 145-7). Pearl millet can now be added to the list of northern elements that were incorporated into what was primarily an indigenous Kintampo cultural milieu. The cultivation of this highly droughtresistant crop would have been an effective adaptation to the wet/dry seasonal climatic regime of the West African savannas (Casey 1998: 53-7; D'Andrea \& Casey in preparation).

The Birimi pearl millet finds have expanded the database on Kintampo subsistence which until now, has been dominated by tropical forest margin species, such as oil palm, incense tree and hackberry, recovered from sites in central and southern Ghana. These species also appear in later West and Central Africa at ceramic LSA sites dating to the 1st millennium BC (Stahl 1993: 272-3; Mbida et al. 2000: 155-8) indicating a widespread tropical West African LSA adaptation to forest-margin environments, emphasizing the exploitation of oleaginous tree fruits. These species, however are notable by their absence in Birimi deposits which are dominated by pearl millet. Macrobotanical assemblages including pearl millet and wild grasses are more typical of sites in the Sahara and Sahel regions farther north (Amblard \& Pernès 1989; 
Klee \& Zach 1999; Neumann 1999). This apparent dichotomy can be explained to some degree by an examination of the present-day ecology of the region. Birimi exists today in dry savanna grassland, more than $500 \mathrm{~km}$ north of the extent of oil palm cultivation. Shea butter tree (Vitellaria paradoxa), not oil palm, is the significant oleaginous species exploited in northern Ghana, the remains of which have not yet been recovered from Birimi deposits. Also, large-scale pearl millet cultivation is limited by precipitation levels to northern Ghana because this crop requires a pronounced dry season (Appa Rao 1985: 25). It appears that regional resource specialization was in existence during the Kintampo as it is today, with southern populations practising a forest-margin adaptation, while further north in wooded savanna grasslands, inhabitants were integrating pearl millet into their subsistence regimes. earlier speculations that domesticated cereals formed a component of Kintampo subsistence. A picture is now emerging of Kintampo peoples partaking in a broad range of subsistence activities that cross-cut the complex ecology
Results presented herein offer support to

of West Africa. This underscores the impressive range of ecological knowledge Kintampo peoples must have had about survival in the varied landscapes at their disposal.

Acknowledgements. This paper is dedicated to the memory of the late Kivilwura Yahaya Seidu of Accra, Ghana.

The Gambaga Archaeological Project was funded by a Social Sciences \& Humanities Research Council of Canada Research Grant to JC in 1995. We would like to thank the Ghana Museums and Monuments Baard and the Ghana Forestry Service for permission to carry out the excavations. Birimi macrobotanical remains were identified using botanical reference collections housed at the Seminar für Vor- und Frühgeschichte, Archäologie und Archäobotanik Afrikas at the University of Frankfurt and personal collections of ACD. In addition, Pennisetum specimens held at the Botanischer Garten und Botanisches Museum Berlin Dahlem were consulted. We are grateful to: Katharina Neumann (University of Frankfurt) for analytical advice; Patrick Hogue (University of British Columbia) and Nicole Jackman (Simon Fraser University) for laboratory assistance; Ann Butler (University College London) who completed the SEM work; Shannon Wood, Cheryl Takahashi and Greg Ehlers (Simon Fraser University) for assistance with illustrations; Dorothy Godfrey-Smith (Dalhousie University) for assistance with charcoal dates; and Larry Pavlish (University of Toronto), Diane Lyons (Simon Fraser University) and two anonymous reviewers for providing valuable comments on various drafts of this manuscript.

\section{References}

ABDEL-MAGID, A. 1989. Plant domestication in the Middle Nile Basin: an archaeobotanical case study. Oxford: British Archaeological Reports. International series S523/Cambridge Monograph in African Archaeology 35 . .

AMBLARD, S. 1996. Agricultural evidence and its interpretation on the Dhars Tichitt and Oualata, southeastern Mali, in Pwiti \& Soper (ed.): 421-8.

AMBLARD, S. \& J. PERNES. 1989 . The identification of cultivated pearl millet (Pennisetum) amongst plant impressions on pottery from Oued Chebbi (Dhar Oualata, Mauritania), African Archaeological Review 7: 117-26.

ANDAH, B.W. 1993. Identifying early farming traditions of West Africa, in Shaw et al. (ed.): 240-54.

ANQUANDAH, J. 1993. The Kintampo Complex: A case study of early sedentism and food production in sub-Sahelian West Africa, in Shaw et al. (ed): 255-60.

APPA RAO, S., M.H. MENGESHA \& D. SHARMA. 1985. Collection and evaluation of pearl millet (Pennisetum americanum) germplasm from Ghana, Economic Botany 39(1): 25-38.

BARAKAT, H. \& A.G. FAHMY. 1999. Wild grasses as 'Neolithic' food resources in the Eastern Sahara: A review of the evidence from Egypt, in M. van der Veen (ed,). The exploitation of plant resources in ancient Africa: 33-46. New York (NY): Kluwer Academic.

BRunken, J.N. 1977. A systematic study of Pennisetum Sect. Pennisetum (Gramineae), American Journal of Botany $64(2): 161-76$.

BRUNKEN, J.N., J.M.J. DEWET \& J.R. HARLAN. 1977. The morphology and domestication of pearl millet, Economic Botany 31: 163-74.

CASEY, J. 1993. The Kintampo Complex in northern Ghana: Late Holocene human ecology on the Gambaga Escarp- ment. Ph.D thesis, Department of Anthropology, University of Toronto.

1998. The ecology of food production in West Africa, in G. Connah (ed.), Transformations in Africa: Essays on Africa's later past: 46-70. London: Leicester University Press.

CASEY, J., R. SAWATSKY, D. GODFREY-SMITH, N. QUICKERT, A.C. D'ANDREA, M. WOLLSTONECROFT \& A. HAWKINS. 1997. Report of investigations at the Birimi Site in northern Ghana, Nyame Akuma 48: 32-8.

CLAYTON, W.D. \& S.A. RENVOIZE. 1982. Flora of Tropical East Africa, Gramineae (Part 3): 672-3. Rotterdam: A.A. Balkema.

D'ANDREA, A.C. \& J. CASEY. In preparation. Pearl millet and Kintampo subsistence.

DAviES, O. 1960. The Neolithic revolution in tropical Africa, Transactions of the Historical Society of Ghana 4(2): 1420.

1962. Neolithic cultures of Ghana, in G. Mortelmans \& J. Nenquin (ed.), Actes du IVe Congrès Panafricain de Préhistoire et de l'Etude du Quaternaire, Section III, Préet protohistoire: 291-302. Tervuren: Musée Royal de l'Afrique Central.

1980. The Ntesero Culture in Ghana, in B.K. Swartz \& R.A. Dumett (ed.), West African Culture Dynamics: 205-25. The Hague: Mouton.

DOMBROWSKI, J.C. 1980. Earliest settlements in Ghana: the Kintampo industry, in R.E. Leakey \& B.A. Ogot (ed.), Proceedings of the VIIIth Panafrican Congress of Prehistory and Quaternary Studies: 261-2. Nairobi: International Louis Leakey Memorial Institute for African Prehistory.

FLIGHT, C. 1968. Kintampo 1967, West African Archaeological Newsletter 8: 15-20. 
1976. The Kintampo Culture and its place in the economic prehistory of West Africa, in J.R. Harlan, J.M.J. deWet \& A.B.L. Stemler (ed.), Origins of African plant domestication: 211-21. The Hague: Mouton.

HARLAN, J.R. 1971. Agricultural origins: centres and non-centres, Science 174: 468-474.

1989. Wild grass harvesting in the Sahara and Sub-Sahara, in D.R. Harris \& G.C. Hillman (ed.), Foraging and Farming: 79-98. London: Unwin Hyman.

KLEE, M. \& B. ZACK. 1999. The exploitation of wild and domesticated food plants at settlement mounds in northeast Nigeria, in van der Veen (ed.): 81-8.

MBIDA, C.M., W. VAN NEER, H. DOUTRELEPONT \& L. VRYDAGHS. 2000. Evidence for banana cultivation and animal hus. bandry during the first millennium $\mathrm{BC}$ in the forest of southern Cameroon, Journal of Archaeological Science $27(2): 151-62$.

NESBITT, R.M.A. 1997. Archaeobotanical identification of Near Eastern grass caryopses. Ph.D thesis, University College London.

NEUMANN, K. 1999. Early plant food production in the West African Sahel: new evidence, in van der Veen (ed.): 7381.

NeUmanN, K., A. Ballovche \& M. KLEE. 1996. The emergence of plant food production in the West African Sahel: new evidence from northeast Nigeria and northern Burkina Faso, in Pwiti \& Soper (ed.): 441-8.

POSNANSKY, M. 1984. Early agricultural societies in Ghana, in J.D. Clark \& S.A. Brandt (ed.), From hunters to formers: 147-51. Berkeley (CA): University of California Press.
PWITI, G. \& R. SOPER (ed.). 1996. Aspects of african archaeology. Harare: University of Zimbabwe Publications.

SHAw, T., P. SinclaIR, B. ANDAH \& A. OKPOKO (ed.). 1993. The archaeology of Africa: food, metals and towns. London: Routledge.

SowUNMI, M.A. 1981. Late Quaternary environmental changes in Nigeria, Pollen et Spores 13(1): 125-48.

STAHL, A.B. 1985. Reinvestigation of Kintampo 6 rock shelter, Ghana: implications for the nature of culture change, African Archaeological Review 3: 117-50.

1986. Early food production in West Africa: rethinking the role of the Kintampo Culture, Current Anthropology 27 (5): $532-6$.

1993. Intensification in the West African Late Stone Age, in Shaw et al. (ed.): 261-73.

TAlbot, M., D.A. Livingstone, P.G. PARKER, J. MALEY, J.M. MELACK, G. DELIBRIAS \& S. GULLIKSEN. 1984. Preliminary results from sediment cores from Lake Bosumtwi, Ghana, Palaeoecology of Africa 16: 173-92.

TOSTAin, S. \& L. MARChaIS. 1993. Evaluation de la diversité génétique des mils (Pennisetum glaucum $(\sim$.) R. BR) au moyen de marqueurs enzymatiques et relations entre formes sauvages et cultivées, in S. Hamon (ed.), Le Mil en Afrique: 33-56. Paris: Éditions de l'ORSTOM.

VAN DER VEEN, M. (ed.). 1999. The exploitation of plant resources in ancient Africa. New York (NY): Kluwer Academic.

WASYLIKOWA, K. 1997. Flora of the 8000 years old archaeological site E-75-6 at Nabta Playa, Western Desert, southern Egypt, Acta Palaeobotanica 37(2): 99-205.

WHITE, F. 1983. The vegetation of Africa Paris: UNESCO. 
Copyright of Antiquity is the property of Antiquity and its content may not be copied or emailed to multiple sites or posted to a listserv without the copyright holder's express written permission. However, users may print, download, or email articles for individual use. 